\title{
The Causality between Capital Formation and Economic Growth in MENA Region
}

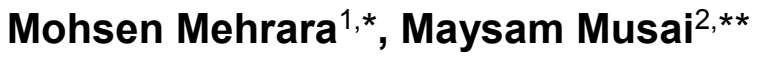 \\ ${ }^{1}$ Faculty of Economics, University of Tehran, Kargar-e-shomali, \\ Po Box 14166-6445, Tehran, Iran \\ ${ }^{2}$ Faculty of Social Sciences, University of Tehran, Tehran, Iran

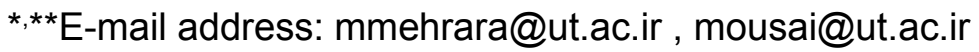

\begin{abstract}
This paper investigates the causal relationship between gross domestic investment (INV) and GDP for Middle East and North Africa (MENA) region countries by using panel unit root tests and panel cointegration analysis for the period 1970-2010. The results show a strong causality from economic growth to investment in these countries. Yet, investment does not have any significant effects on GDP in short- and long-run. It means that it is the GDP that drives investment in mentioned countries, not vice versa. So the findings of this paper support the point of view that it is higher economic growth that leads to higher investment. According to the results, decision makings should be employed to achieve sustainable growth through higher productivity and substantially enlarging the economic base diversification in the future.
\end{abstract}

Keywords: Panel Unit Root; Panel Cointegration; Granger Causality; Gross Domestic Investment (INV); MENA region countries

JEL classifications: $\mathrm{C} 12 ; \mathrm{C} 33$; E21; F43

\section{INTRODUCTION}

There is robust empirical evidence indicating that there is a positive correlation between investment and growth. There is, however, no consensus about the direction of the causality between them. This issue can be explained with several hypotheses. The first one is that increased investment may enhance economic growth (Bebczuk 2000). This approach is confirmed by Harrod (1939), Domar (1946) and Solow (1956) growth models. Tyler (1981) investigating a sample of 55 developing countries showed that investment is the main determinant of growth rate. New growth theories insist on the importance of investments, human and physical capital in the long-run economic growth. The policies, which affect the level of growth and the investment productivity, determine the long-run economic growth. Theoretically, the gross investment affects the economic growth through either increasing the physical capital stock, or promoting the technology (Levine and Renelt, 1992 and Plossner, 1992). The second hypothesis is that economic growth stimulates increased investment. Blomstrom et al. (1996), based on econometric results of the Granger causality tests indicate 
that the direction of causality runs from economic growth to investment. That is, it is the GDP growth that leads to more investment in the economy. Therefore, they conclude something else except investment should explain economic growth including economic and political environment, productivity, education, foreign investment and so on.

The focus of the paper is, therefore, to examine the relationship between investment and economic growth in Middle East and North Africa (MENA) region countries for the period 1970-2010 The direction of causality between these two variables is examined by utilizing a cointegration and error correction modeling framework. The paper is organized in four sections. Section 2 discusses the methodology, data and empirical results of the study. Section 3 concludes.

\section{DATA AND EMPIRICAL RESULTS}

We apply a two variable model to examine the causal relationship between investment and GDP. Data used in the analysis are annual time series during the period 1970-2010 on (logarithm of) real gross domestic investment (INV) and real GDP per capita (GDP) in constant 2000 prices in local currency units for Middle East and North Africa (MENA) region countries. The MENA countries covered in this study are Egypt, Iran, Jordan, Saudi Arabia, Morocco, Tunisia, Turkey and Yemen. The data were obtained from World Development Indicators (WDI) 2010, published by the World Bank. The choice of the starting period was constrained by the availability of data.

To test the nature of association between the variables while avoiding any spurious correlation, the empirical investigation in this paper follows the three steps: We begin by testing for non-stationarity in the variables of INV and GDP. Prompted by the existence of unit roots in the time series, we test for long run cointegrating relation between variables at the second step of estimation using the panel cointegration technique developed by Pedroni $(1995,1999)$. Granted the long run relationship, we explore the causal link between the variables by testing for granger causality at the final step.

\section{1. Panel Unit Roots Results}

The panel data technique referred above has appealed to the researchers because of its weak restrictions. It captures country specific effects and allows for heterogeneity in the direction and magnitude of the parameters across the panel. In addition, it provides a great degree of flexibility in model selection. Following the methodology used in earlier works in the literature we test for trend stationarity of the variables of INV and GDP. With a null of nonstationary, the test is a residual based test that explores the performance of four different statistics. Together, these four statistics reflect a combination of the tests used by Levin-Lin (1993) and Im, Pesaran and Shin (1997). While the first two statistics are non-parametric rhostatistics, the last two are parametric ADF t-statistics. Sets of these four statistics have been reported in Table 1.

The first three rows report the panel unit root statistics for INV and GDP at the levels. As we can see in the table, we cannot reject the unit-root hypothesis when the variables are taken in levels and thus any causal inferences from the series in levels are invalid. The last rows report the panel unit root statistics for first differences of INV and GDP. The large negative values for the statistics indicate rejection of the null of non-stationary at $1 \%$ level for all variables. It may, therefore be concluded that the variables of INV and GDP are unit root variables of order one, or, I (1) for short. 
Table 1. Test of Unit Roots for INV and GDP.

\begin{tabular}{ccccc}
\hline Variables & $\begin{array}{c}\text { Levin-Lin } \\
\text { Rho-stat }\end{array}$ & $\begin{array}{c}\text { Levin-Lin } \\
\text { t-Rho-stat }\end{array}$ & $\begin{array}{c}\text { Levin-Lin } \\
\text { ADF stat }\end{array}$ & IPS ADF stat \\
\hline & & & & \\
$I N V$ & 0.21 & -0.52 & -0.98 & -1.34 \\
$G D P$ & -1.12 & -1.18 & -1.25 & -0.54 \\
$\Delta I N V$ & $-12.30^{* * *}$ & $-7.39^{* * *}$ & $-8.71^{* * *}$ & $-17.56^{* * *}$ \\
$\Delta G D P$ & $-11.67^{* * *}$ & $-7.84^{* * *}$ & $-9.83^{* * *}$ & $-18.52^{* * *}$ \\
\hline$* * *$ significant at $1 \%$ & & & &
\end{tabular}

\section{2. Panel Cointegration Results}

At the second step of our estimation, we look for a long run relationship among INV and GDP using the panel cointegration technique developed by Pedroni (1995, 1999). This technique is a significant improvement over conventional cointegration tests applied on a single country series. While pooling data to determine the common long run relationship, it allows the cointegrating vectors to vary across the members of the panel. The cointegration relationship we estimate is specified as follows:

$$
I N V_{i t}=\alpha_{i}+\delta_{t}+\beta_{i} G D P_{i t}+\varepsilon_{i t}
$$

where $\alpha_{i}$ refers to country effects and $\delta_{t}$ refers to trend effects. $\varepsilon_{i t}$ is the estimated residual indicating deviations from the long run relationship.

With a null of no cointegration, the panel cointegration test is essentially a test of unit roots in the estimated residuals of the panel. Pedroni (1999) refers to seven different statistics for this test. Of these seven statistics, the first four are known as panel cointegration statistics; the last three are group mean panel cointegration statistics. In the presence of a cointegrating relation, the residuals are expected to be stationary.

These tests reject the null of no cointegration when they have large negative values except for the panel-v test which reject the null of cointegration when it has a large positive value. All of these seven statistics under different model specifications are reported in Table 2. The statistics for all different model specifications suggest rejection of the null of no cointegration for all tests except the panel and group $\rho$-tests. However, according to Perdroni (2004), $\rho$ and PP tests tend to under-reject the null in the case of small samples. We, therefore, conclude that the variables INV and GDP are cointegrated in the long run. 
Table 2. Results of Panel Cointegration test.

\begin{tabular}{ll}
\hline Statistics & \\
\hline Panel v-stat & $7.52^{* * *}$ \\
Panel Rho-stat & -0.63 \\
Panel PP-stat & $-5.12^{* * *}$ \\
Panel ADF-stat & $-2.10^{* *}$ \\
& \\
Group Rho-stat & $-0.41^{* * *}$ \\
Group PP-stat & $-6.61^{* * *}$ \\
Group ADF-stat & $-7.91^{* * *}$ \\
\hline$* * *$ significant at $1 \%$ & \\
$* *$ significant at $5 \%$ &
\end{tabular}

\section{3. Panel Causality Results}

Cointegration implies that causality exists between the series but it does not indicate the direction of the causal relationship. With an affirmation of a long run relationship among INV and GDP, we test for Granger causality in the long run relationship at the third and final step of estimation. Granger causality itself is a two-step procedure. The first step relates to the estimation of the residual from the long run relationship. Incorporating the residual as a right hand side variable, the short run error correction model is estimated at the second step. Defining the error term from equation (1) to be $E C T_{i t}$, the dynamic error correction model of our interest is specified as follows:

$$
\begin{aligned}
& \Delta G D P_{i t}=\alpha_{y i}+\beta_{y i} E C T_{i t-1}+\gamma_{y 1 i} \Delta I N V_{i t-1}+\gamma_{y 2 i} \Delta I N V_{i t-2}+ \\
& \delta_{y 1 i} \Delta G D P_{i t-1}+\delta_{y 2 i} \Delta G D P_{i t-1}+\varepsilon_{y i t} \\
& \Delta I N V_{i t}=\alpha_{h i}+\beta_{h i} E C T_{i t-1}+\gamma_{h 1 i} \Delta I N V_{i t-1}+\gamma_{y 2 i} \Delta I N V_{i t-2}+ \\
& \delta_{h 1 i} \Delta G D P_{i t-1}+\delta_{h 2 i} \Delta G D P_{i t-1}+\varepsilon_{h i t}
\end{aligned}
$$

where $\Delta$ is a difference operator; ECT is the lagged error-correction term derived from the long-run cointegrating relationship; the $\beta_{y}$ and $\beta_{h}$ are adjustment coefficients and the $\varepsilon_{y i t}$ and $\varepsilon_{\text {hit }}$ are disturbance terms assumed to be uncorrelated with mean zero. 
Sources of causation can be identified by testing for significance of the coefficients on the lagged variables in Eqs (2) and (3). First, by testing $H_{0}: \gamma_{y 1 i}=\gamma_{y 2 i}=0$ for all i in Eq. (2) or $H_{0}: \delta_{h 1 i}=\delta_{h 2 i}=0$ for all $\mathrm{i}$ in Eq. (3), we evaluate Granger weak causality. Masih and Masih (1996) and Asafu-Adjaye (2000) interpreted the weak Granger causality as 'short run' causality in the sense that the dependent variable responds only to short-term shocks to the stochastic environment.

Another possible source of causation is the ECT in Eqs. (2) and (3). In other words, through the ECT, an error correction model offers an alternative test of causality (or weak exogeneity of the dependent variable). The coefficients on the ECTs represent how fast deviations from the long run equilibrium are eliminated following changes in each variable. If, for example, $\beta_{y i}$ is zero, then GDP does not respond to a deviation from the long run equilibrium in the previous period. Indeed $\beta_{y i}=0$ or $\beta_{h i}=0$ for all $\mathrm{i}$ is equivalent to both the Granger non-causality in the long run and the weak exogeneity (Hatanaka, 1996).

It is also desirable to check whether the two sources of causation are jointly significant, in order to test Granger causality. This can be done by testing the joint hypotheses $H_{0}: \beta_{y i}=0$ and $\gamma_{y 1 i}=\gamma_{y 2 i}=0$ for all $\mathrm{i}$ in Eq. (2) or $H_{0}: \beta_{h i}=0$ and $\delta_{h 1 i}=\delta_{h 2 i}=0$ for all $\mathrm{i}$ in Eq. (3). This is referred to as a strong Granger causality test. The joint test indicates which variable(s) bear the burden of short run adjustment to re-establish long run equilibrium, following a shock to the system (Asafu-Adjaye, 2000).

The results of the F test for both long run and short run causality are reported in Table 3. As is apparent from the Table, the coefficients of the ECT and GDP are significant in the INV equation which indicates that long-run and short-run causality run from GDP to investment. So, GDP strongly Granger-causes investment. Weak exogeneity of GDP indicate that this variable does not adjust towards long-run equilibrium.

Moreover, the interaction terms in the INV equation are significant at $1 \%$ level. These results imply that, there is Granger causality running from GDP to investment in the long-run and short run, while investment have a neutral effect on GDP in both the short- and long-run. In other words, GDP is strongly exogenous and whenever a shock occurs in the system, investment would make short-run adjustments to restore long-run equilibrium.

Table 3. Result of Panel causality tests.

\section{Source of causation (independent variable)}

\begin{tabular}{|c|c|c|c|c|c|}
\hline \multirow{2}{*}{$\begin{array}{l}\text { Dependent } \\
\text { Variable }\end{array}$} & \multicolumn{2}{|l|}{ Short-run } & \multirow{2}{*}{$\begin{array}{l}\text { Long-run } \\
\text { ECT(-1) }\end{array}$} & \multicolumn{2}{|c|}{ Joint (short-run/long-run) } \\
\hline & $\Delta \mathrm{GDP}$ & $\Delta \mathrm{INV}$ & & $\begin{array}{c}\Delta \mathrm{GDP} \\
\mathrm{ECT}(-1)\end{array}$ & $\begin{array}{c}\Delta \mathrm{INV}, \\
\mathrm{ECT}(-1)\end{array}$ \\
\hline$\Delta \mathrm{GDP}$ & - & $\mathrm{F}=0.25$ & $\mathrm{~F}=0.48$ & - & $\mathrm{F}=0.39$ \\
\hline$\Delta \mathrm{INV}$ & $\mathrm{F}=4.90^{* *}$ & - & $\mathrm{F}=6.14^{* * *}$ & $\mathrm{~F}=7.61^{* * *}$ & - \\
\hline
\end{tabular}




\section{CONCLUSION}

The objective of this study is to examine Granger causality between investment and income for MENA region countries over the period 1970-2010. The panel integration and cointegration techniques are employed to investigate the relationship between the variables: investment and GDP. The empirical results indicate that we cannot find enough evidence against the null hypothesis of unit root. However, for the first difference of the variables, we rejected the null hypothesis of unit root. It means that the variables are I(1). The results show that there is a long-run relationship between investment and GDP. Utilizing Granger Causality within the framework of a panel cointegration model, the results suggest that there is strong causality running from GDP to investment with no feedback effects from investment to GDP MENA region countries. Moreover, investment has significant effects on GDP just in shortrun. It means that it is the GDP that drives the investment in mentioned countries, not vice versa. So the findings of this paper support the point of view that it is higher economic growth that leads to higher investment.

According to the results, policymakers should take a way to accelerate economic growth through enhancing total factor productivity so as to increase investment in the mentioned countries. For this purpose, the governments of the countries under investigation should increase their productive investments and infrastructures like power, roads, education and so on to reduce the costs of doing business. Providing the higher political stability in the countries, encouragement of inflows of foreign direct investment, and increasing the war on corruption are some other recommendations.

\section{Acknowledgements}

The authors would like to acknowledge the financial support of university of Tehran for this research under the grant number 4401012/1/19.

\section{References}

[1] Agrawal, P. (2000). Savings, Investment and Growth in South Asia. Indira Gandhi Institute of Development Research.

[2] Asafu-Adjaye, J. (2000). The Relationship between Energy Consumption, Energy Prices and Economic Growth: Time Series Evidence from Asian Developing Countries, Energy Economics, 22, 615-625.

[3] Blomstrom, M., Lipsey, R. E., Zejan, M. (1996). Is fixed investment the key to economic growth? Quarterly Journal of Economics February, 269-276.

[4] De Long, J. B., Summers, L. (1991). Equipment investment and economic growth. Quarterly Journal of Economics, CVI, 445-502.

[5] De Long, J. B., L. Summers, (1992). Equipment investment and economic growth: How strong is the nexus? Brookings Papers on Economic Activity, 157-211.

[6] Domar, E. D. (1946). Capital Expansion, Rate of Growth, and Employment, Econometrica, 14, 137-147. 
[7] Granger, C. W. J. (1969). Investigating Causal Relations by Econometric Models and Cross-spectral Methods, Econometrica, 37(3), 424-438.

[8] Granger, C. W. J. (1988). Some Recent Developments in a Concept of Causality, Journal of Econometrics, 39, 199-211.

[9] Harrod, R. F., (1939). An Essay on Dynamic Theory. Economic Journal, 49, 14-33.

[10] Hatanaka, M., (1996). Time-Series-Based Econometrics: Unit Roots and Co-integration. Oxford University Press, Oxford.

[11] Im, K. S., Pesaran, M. H., Shin, Y. (1997). Testing for Unit Roots in Heterogeneous Panels, University of Cambridge, Department of Applied Economics.

[12] Im, K. S., Pesaran, M. H., Shin, Y. (2003). Testing for Unit Roots in Heterogeneous Panels, Journal of Econometrics, 115, 53-74.

[13] Levin, A., Lin, C. F. (1992). Unit Root Tests in Panel Data: Asymptotic and Finite Sample Properties. Department of Economics, University of California at San Diego, Working Paper 92-23.

[14] Levin, A., Lin. C. F. (1993). Unit Root Test in Panel Data: New Results. Department of Economics, University of California, San Diego, Working paper 93-56.

[15] Levin, A., Lin, C. F., Chu, C. S. J. (2002). Unit Root Test in Panel Data: Asymptotic and Finite Sample Properties. Journal of Econometrics, 108, 1-24.

[16] Masih, A. M. M., Masih, R. (1996). Energy consumption, real income and temporal causality: results from a multi-country study based on cointegration and error-correction modeling techniques. Energy Economics, 18, 165-183.

[17] Pedroni, P. (1995). Panel Cointegration: Asymptotic and Finite Sample Properties of Pooled Time Series Tests, with an Application to the PPP Hypothesis. Indiana University, Working Papers in Economics, No. 95-013.

[18] Pedroni, P. (1997). Panel Cointegration: Asymptotic and Finite Sample Properties of Pooled Time Series Tests, with an Application to the PPP Hypothesis: New results, India University, Working Papers in Economics.

[19] Pedroni, P. (1999). Critical Values for Cointegration Tests in Heterogeneous Panels with Multiple Regressors. Oxford Bulletin of Economics and Statistics, 61(4), 5-49.

[20] Pedroni, P. (2004). Panel Cointegration: Asymptotic and Finite Sample Properties of Pooled Time Series Tests with an Application to the PPP Hypothesis: New Results. Econometric Theory, 20(3), 597-627.

[21] Pesaran, M. H., Shin Y. (1997). An Autogressive Distributed Lag Modelling Approach to Cointegration Analysis, Working Paper Trinity College, Cambridge.

[22] Solow, R. M. (1956). A Contribution to the Theory of Economic Growth. Quarterly, Journal of Economics, 70, 65-94.

[23] Mohsen Mehrara, Maysam Musai, International Letters of Social and Humanistic Sciences 5 (2013) 55-62. 